\title{
PENGARUH PENGGUNAAN GADGET TERHADAP INTERAKSI SOSIAL PADA SISWA KELAS X IPS SMA KRISTEN SATYA WACANA SALATIGA
}

\author{
Yuliana Bewu', Yari Dwikurnaningsih ${ }^{2}$,Yustinus Widrawanto ${ }^{3}$ \\ Email : bewuyuliana@gmail.com \\ Program Studi Bimbingan dan Konseling, Fakultas Keguruan dan Ilmu Pendidikan \\ Universitas Kristen Satya Wacana ${ }^{1,2,3}$
}

\begin{abstract}
ABSTRAK
Penelitian ini bertujuan untuk mengetahui signifikansi pengaruh penggunaan gadget terhadap interaksi sosial siswa. Subyek penelitian ini adalah siswa kelas X IPS SMA Kristen Satya Wacana Salatiga yang berjumlah 54 siswa. Teknik pengambilan sampel yang digunakan adalah Total Sampling. Teknik pengumpulan data untuk penggunaan gadget menngunakan kuesioner yang disusun oleh Chusna Oktia Roman (2017) bedasarkan teori Chriany Judhita sedangkan untuk data interaksi sosial menggunakan skala sikap yang disusun oleh Agung Prasetio (2017) berdasarkan teori Partowisastro. Metode analisis data yang digunakan adalah regresi linear sederhana yang diolah dengan bantuan program SPSS for Windows 16.0. Berdasarkan analisis data didapatkan hasil $R$ Square $=0,01(0,1 \%)$ yang berarti bahwa variabel penggunaan gadget memberikan pengaruh terhadap interaksi sosial hanya sebesar $0,1 \%$ dan untuk $99,9 \%$ oleh faktor lain yang tidak dijelaskan dalam penelitian ini. Sedangkan untuk hasil Anova diperoleh hasil f hitung (0.042) dan sig (0.838>0.05), serta pada data Coefficients diperoleh hasil T hitung (0.205). Dapat disimpulkan bahwa tidak ada pengaruh yang signifikan penggunaan gadget terhadap interaksi sosial siswa kelas X SMA Kristen Satya Wacana Salatiga tahun ajaran 2018/2019
\end{abstract}

Kata Kunci : Siswa Kelas X IPS SMA, Penggunaan Gadget, Interaksi Sosial.

PENDAHULUAN

$$
\text { Perkembangan teknologi, }
$$

informasi, dan komunikasi begitu cepat sehingga tanpa kita sadari bahwa banyak yang mempengaruhi aspek - aspek kehidupan manusia. Seiring berjalannya waktu maka arus globalisasi dan pertukaran informasi yang cepat maka dapat menyebabkan peranan teknologi komunikasi menjadi sangat penting. Penggunaan Gadget di kalangan pelajar masa kini merupakan sebuah keharusan untuk memilikinya, misalnya handphone, tablet, laptop, dan berbagai macam gadget lainnya. Gadget dapat merubah makna dari "kesendirian", dapat menjadi suatu suasana yang lebih ramai dan hidup. Dengan satu gadget yang canggih saja kita bisa mendengarkan berbagai macam seperti mendengarkan musik, bermain games, bermain internet, melihat foto-foto, menonton video, dan lain-lain meskipun berada dalam satu ruangan sendirian tanpa ada apapun. Interaksi sosial dapat berguna bagi siswa dalam mengembangkan pemikiran sosial, yang berkenaan dengan pengetahuan dan keyakinan mereka tentang masalah hubungan dan keterampilan sosial. Peningkatan jumlah penggunaan gadget serta cara berkomunikasi yang berubah - ubah maka suatu kesenangan dalam penggunaan alat-alat teknologi guna membantu dan mempermudahkan aktivitas- aktivitas manusia, tetapi disatu sisi penggunaan 
teknologi yang semakin meningkat justru menurunkan intensitas hubungan individu. Menurut Interaksi sosial yang terjadi lewat media membuat ikatan solidaritas sosial siswa menjadi melemah ( Ameliola \& Nugraha 2013).

Gadget adalah barang canggih yang diciptakan dengan berbagai aplikasi yang dapat menyajikan berbagai media seperti berita, jejaring sosial, hobi, bahkan hiburan, ini adalah salah satu tanda kemajuan dari teknologi. Meningkatnya penggunaan gadget atau alat-alat yang dapat dengan mudah maka terkoneksi dengan internet ini, mengalami peningkatan dari waktu ke waktu. Saat ini kurang lebih 45 juta menggunakan internet, dimana sembilan juta diantaranya menggunakan ponsel untuk mengakses internet. Pada tahun 2001, jumlah pengguna internet di Indonesia hanya setengah juta penduduk. Jumlah penggunaan internet semakin bertambah karena semakin mudah di dapat serta terjangkaunya harga (Sanjaya \& Wibhowo, 2011). Dalam survey yang dilakukan oleh Badan Pusat Statistik (BPS) yang bekerja sama dengan Asosiasi Penyelenggara Jasa Internet Indonesia (APJII), mencatat bahwa pengguna internet di Indonesia hingga akhir tahun 2013 mencapai 71,19 juta orang, survei ini dilakukan pada 78 kabupaten/kota dan 33 provinsi. Jumlah tersebut mengalami kenaikan di bandingkan dengan hasil survei tahun 2012 yaitu sebanyak 63 juta orang. Itu berarti mengalami kenaikan sebanyak 13 persen. Barang canggih ini yang dilihat dari segi harga yang tidak bisa dibilang murah tidak hanya sekedar dijadikan media hiburan semata tapi dengan aplikasi yang terus diperbaharui gadget wajib digunakan oleh orang-orang yang memiliki kepentingan bisnis, atau mengerjakan tugas kuliah dan kantor, akan tetapi pada faktanya gadget tak hanya digunakan oleh orang dewasa atau lanjut, remaja (12-21 tahun), usia 22 tahun keatas,tapi pada anak-anak usia (711tahun) dan lebih parahnya lagi gadget digunakan oleh anak usia (3-6 tahun), yang seharusnya belum layak untuk menggunakan gadget (Widiawati \& Sugiman, 2014). Berdasarkan observasi yang sudah di lakukan oleh peneliti di SMA Kristen Satya Wacana Salatiga, bahwa semua siswa kelas $\mathrm{X}$ IPS menggunakan gadget. Gadget di gunakan untuk membantu para siswa mencari referensi dalam mengerjakan tugas sekolah. Dengan adanya gadget para siswa dapat melakukan komunikasi baik jarak jauh maupun jarak dekat. Selain itu siswa bisa berkomunikasi satu sama lain dengan tujuan untuk menanyakan 
tugas yang kurang di pahami,melalui media sosial seperti facebook, twitter, email, blog, BBM, whatshap dan lainlain. Dengan adanya gadget yang mereka miliki dapat dijadikan media refresing sekaligus hiburan ketika mereka lelah dan jenuh setelah menyelesaikan tugas-tugas mereka. Seperti bermain game dan chatting.

\section{KAJIAN PUSTAKA}

\section{Interaksi Sosial}

Menurut Kulsum \& Jauhar (2014) Interaksi sosial merupakan hubungan hubungan sosial yang dinamis, yang menyangkut hubungan antara perorangan seperti hubungan ibu dan anak, antara kelompok-kelompok seperti anggota kelas yang satu dengan kelas yang lain, maupun antara orang perorangan dengan kelompok seperti guru dan muridnya. Menurut Soerjono Soekanto \& Budi Sulistyowati, (2013) Interaksi sosial merupakan kunci dari semua kehidupan sosial. interaksi sosial merupakan syarat utama terjadinya aktivitas-aktivitas sosial. Dalam kehidupan ini, tidak ada manusia yang dapat hidup sendiri tanpa adanya interaksi dengan lingkungan di sekitarnya. Herimanto \& Winarno, (2013) mengungkapkan bahwa interaksi sosial merupakan faktor utama dalam kehidupan sosial. Interaksi sosial merupakan suatu hubungan sosial yang dinamis, menyangkut adanya hubungan timbal balik antar individu, antar kelompok, maupun individu dengan kelompok. Interaksi sosial berhubungan dengan sikap manusia, karena interaksi sosial merupakan perilaku seseorang berhubungan dengan orang yang lain.

1) Syarat - Syarat Interaksi Sosial menurut Soerjono dalam Nurani Suyomukti, (2016) interaksi sosial tidak akan mungkin terjadi apa bila tidak memenuhi dua syarat adalah :

a. Adanya kontak sosial

Kata kontak berasal dari bahasa latin con atau cum ( yang artinya bersama - sama ) dan tango ( yang artinya menyentuh ) jadi arti secara harafiah adalah bentuk bersama - sama menyentuh . Secara fisik, kontak baru terjadi apa bila terjadi hubungan badaniah, oleh karena orang dapat mengadakan hubungan dengan pihak lain tanpah penyentuhnya misalnya dengan cara berbicara dengan pihak lain tersebut.

b. Adanya komunikasi

Arti penting dari komunikasi adalah bahwa seseorang memberika tafsiran pada perilaku orang lain ( yang berwujud pembicaraan, gerak - 
gerak badaniah atau sikap), perasaan perasaan apa yang di ingin di sampaikan oleh orang tersebut. Dengan adanya komunikasi tersebut sikap sikap dan perasaan - perasaan suatu kelompok manusia atau orang perseorangan dapat di ketahui oleh kelompok kelompok lain atau orang orang lainnya.

2) Bentuk - Bentuk Interaksi Sosial

Mengacu pendapat Gillin \& Gillin yang dikutip oleh Soerjono Soekanto, (2004 ) penggolongan secara luas mengeai proses sosial yang timbul akibat interaksi sosial meliputi dua hal yaitu proses asosiatif meliputi akomodasi, asimilasi, akulturasi. Proses disosiatif yang meliputi contravetion dan pertentangan pertikaian atau konflik.Ilmiwan lainya, Kimbal Young, memberkan sistematika yang berbeda. Menurutnya, bentuk bentuk prosesosial, antara lain:

1) Oposisi ( opposition ) yang mencakup pertikaian (competition) dan pertikaian ( conflinct)

2) Kerja sama ( co- operation) yang menghasilkan akomodasi (acomodation)
3) Diferentiation yang merupakan proses ketika individu - individu di dalam masyarakat memperoleh hak - hak dan kewajiban kewajiban yang berbeda dengan orang lain dalam masyrakat atau dasar perbedaan usia, jenis kelamin, dan pekerjaan. Diferensasi tersebut menghasilkan sistem sosial berlapi - lapis.

3) Faktor - Faktor Interaksi Sosial Kelangsungan interaksi sosial, sekalipun dalam bentuknya yang sederhana, ternyata merupakan proses yang kompleks, tetapi dapat kita beda-bedakan beberapa faktor yang mendasarinya, baik secara tunggal maupun bergabung, yaitu Vide Bonner, (2014)

1. Faktor imitasi

2. Faktor sugesti

3. Faktor identifikasi

4. Faktor sipati

4) Aspek - Aspek Interaksi Sosial Menurut Partowisastro (dalam Saputra, 2010) aspek-aspek interaksi sosial digolongkan menjadi tiga aspek, yaitu:

a) kontak sosial yaitu menjalin hubungan akrab 
b) Individu akan terlibat dalam kegiatan kelompoknya dan mau menyumbangkan ide bagi kemajuan kelompoknya.

c) Frekuesi hubungan dalam kelompoknya.

\section{Penggunaan Gadget}

Widiawati \& Sugiman (2014) Gadget merupakan barang canggih yang diciptakan dengan berbagai aplikasi yang dapat menyajikan berbagai media berita, jejaring sosial, hobi, bahkan hiburan. Irawan, (2013) Gadget yang saat ini banyak digemari masyarakat khususnya kalangan remaja, mempunyai beberapa jenis-jenis gadget yang sering digunakan. Ma'ruf (2015) Gadget adalah sebuah benda (alat atau barang eletronik) teknologi kecil yang memiliki fungsi khusus , tetapi sering diasosiasikan sebagai sebuah inovasi atau barang baru. Gadget selalu diartikan lebih tidak biasa atau didisain secara lebih pintar dibandingkan dengan teknologi normal pada masa penemuannya. Bahkan gadget memang cenderung di targetkan kepada anak-anak usia sekolah atau remaja. Mereka sekarang ini sudah sangat akrab sekali degan teknologi yang satu ini. Berbagai kemudahan dan kecangihan memang di tawarkan dengan mudah oleh piranti elktronik yang satu ini, sehingga masyarakat seolah-olah mau tidak mau menjadi ketergantugan dengan alat elektronik ini. Pada mulanya gadget memang lebih difokuskan kepada sebuah alat komunikasi,namun semenjak kemauan jaman alat ini di percangih dengan berbagai fitur-fitur yang ada didalam nya sehingga memungkinkan penggunanya untuk melakukan semua hal hal tersebut, gadget juga memiliki dampak positif dan negatif bagi siapa saja penikmatnya. Orang tua harusnya mampu memantau anak-anaknya dalam menggunakan gadget dengan baik agar tidak menimbulkan dampak negatif. Jenis jenis gadget menurut Irawan (2013) adalah sebagai berikut:

a. Iphone Merupakan sebuah telepon yang memiliki koneksi internet.

b. Ipad Merupakan sebuah gadget yang memiliki ukuran lebih besar.

c. Blackberry Merupakan sebuah perangkat genggam nirkabel dengan berbagai kemampuan. Alat ini dapat digunakan untuk SMS, faksimili internet, dan juga telepon seluler

d. Netbook Merupakan sebuah alat perpaduan antara komputer portbel.

e. Handphone Merupakan sebuah alat atau perangkat komunikasi 
elektronik tanpa kabel. Sehingga

alat ini dapat dibawa

kemanamana dan memiliki

kemampuan dasar yang sama

halnya dengan telepon

konvensional saluran tetap.

Menurut Fadila (2015) ada beberapa faktor yang mempengaruhi remaja dalam penggunaan gadget. Faktor-faktor tersebut meliputi:

a. Iklan yang merajalela di dunia pertelevisian dan di media sosial

b. Kecanggihan dari gadget..

c. Keterjangkauan harga gadget

Penggunaan gadget dikalangan remaja tentunya akan menimbulkan dampak bagi remaja, dampak yang terjadi berupa dampak positif dan negatif. Dampak positif penggunaan gadget menurut Harfiyanto (dkk,2015).

1. Dampak positif
a. Memudahkan
untuk berinteraksi dengan orang banyak lewat media sosial. Sehingga memudahkan untuk saling berkomunikasi dengan orang baru dan memperbanyak teman.
b. Mempersingkat jarak dan waktu, karena dalam era perkembangan gadget yang canggih didalamnya terdapat

media sosial seperti sekarang ini.

c. Hubungan jarak jauh tidak lagi menjadi masalah dan menjadi halangan. Hal ini biasa dilakukan remaja dengan sms atau bbm kepada guru mata pelajaran.

2. Dampak negatif

Dampak negatif penggunaan gadget menurut Derry Iswidharmanjaya (2014: 16) adalah sebagai berikut :
a. Menjadi pribadi yang tertutup
b. Kesehatan terganggu.
c. Gangguan tidur.
d. Suka menyendiri.
e. Penyakit mental
f. Agresif.
g. Adikasi

Aspek Aspek penggunaan gadget menurut Christiany Judhita (2011: 14)

a) Penggunaan tinggi yaitu pada intensitas penggunaan lebih dari 3 jam dalam sehari.

b) Penggunaan sedang yaitu pada intensitas penggunaan sekitar 3 jam dalam sehari.

c) rendah yaitu pada intensitas pengguna an kurang dari 3 jam dalam sehari. 


\section{METODE PENELITIAN}

Penelitian ini menggunakan metode kuantitatif dengan pendekatan penelitian inferensial. Penelitian inferensial yaitu suatu penelitian dengan melakukan analisis hubungan antar variabel dengan pengujian hipotesis. Dengan demikian kesimpulan penelitian jauh melampaui data kuantitatif. Teknik analisis yang digunakan dalam penelitian ini yaitu teknik Analisis Regresi Linier sederhana Umu Nadhiroh, (2010). Menurut Sugiyono, (2012) analisis regresi linier sederhana adalah hubungan secara linier antara satu variabel independen (X) dengan variabel dependen (Y). Analisis ini untuk mengetahui arah hubungan antara variabel independen dengan variabel dependen apakah positif atau negatif serta untuk memprediksi nilai dari variabel dependen apabila nilai variabel independen mengalami kenaikan dan penurunan.

Teknik analisis data yang sudah terkumpul akan dibuat dalam bentuk tabel kemudian dilakukan analisis secara statistik. Teknik analisis data ini digunakan untuk menjawab rumusan masalah atau menguji hipotesis yang telah dirumuskan dalam penelitian. Dalam penelitian ini menggunakan teknik analisis regresi linier sederhana. Pengolahan data yang dilakukan dengan menggunakan program Software SPSS versi. 16. Agar kesimpulan yang diambil tidak menyimpang, maka syarat dari regresi linier sederhana adalah uji normalitas. Uji normalitas bertujuan untuk menentukan teknik analisis data yang tepat. Uji normalitas digunakan untuk mengetahui data yang dianalisis berdistribusi normal atau tidak. Jika data berdistribusi normal maka dapat digunakan teknik analisis data Parametrik, jika data berdistribusi tidak normal maka dapat digunakan teknik analisis data Non Parametrik.

\section{HASIL DAN PEMBAHASAN}

Hasil analisis penelitian penggunaan gadget dan interaksi sosial merangkum gambaran data yang telah diklasifikasikan berdasarkan 4 kategori yaitu sangat tinggi, tinggi, rendah, dan sangat rendah.

Tabel 1. Gambaran Penggunaan Gadget

\begin{tabular}{|l|l|l|l|}
\hline Kategori & Rentang Skor & Frekuensi(f) & Persentase (\%) \\
\hline Sangat Tinggi & $37-44$ & 6 & 11 \\
\hline Tinggi & $29-36$ & 21 & 39 \\
\hline Sedang & $20-28$ & 24 & 44 \\
\hline Rendah & $11-19$ & 3 & 6 \\
\hline Jumlah & & $\mathbf{5 4}$ & 100 \\
\hline
\end{tabular}

Tabel 2. Gambaran Interaksi Sosial

\begin{tabular}{l|l|l|l|}
\hline Kategori & Rentang Skor & Frekuensi (f) & Persentase (\%) \\
\hline Sangat Tinggi & $90-110$ & 6 & 11 \\
\hline Tinggi & $68-89$ & 10 & 19 \\
\hline Sedang & $48-68$ & 32 & 59 \\
\hline Rendah & $27-47$ & 6 & 11 \\
\hline Jumlah & 54 & 100 \\
\hline
\end{tabular}


Tabel 3. Uji Normalitas Interaksi Sosial Tests of Normality

\begin{tabular}{|l|l|l|l|l|l|l|}
\hline \multirow{2}{*}{} & \multicolumn{5}{|c|}{ Sh } \\
& \multicolumn{4}{|c|}{ Kolmogoro-Smirnov ${ }^{a}$} & \multicolumn{2}{l|}{ apiro-Wilk } \\
\cline { 2 - 7 } & Statistic & Df & Sig. & Statistic & df & Sig. \\
\hline Interaksi & .114 & 54 & .076 & .967 & 54 & .138 \\
\hline
\end{tabular}

a. Lilliefors Significance Correction

\section{Model Summary}

\begin{tabular}{|l|l|l|l|l|}
\hline Model & $\mathrm{R}$ & $\mathrm{R}$ Square & $\begin{array}{l}\text { Adjusted R } \\
\text { Square }\end{array}$ & $\begin{array}{l}\text { Std. Error of the } \\
\text { Estimate }\end{array}$ \\
\hline 1 & $.028^{\mathrm{a}}$ & .001 & -.018 & 15.455 \\
\hline
\end{tabular}

a. Predictors: (Constant), gadget

ANOVA

\begin{tabular}{|c|c|c|c|c|c|}
\hline Model & $\begin{array}{l}\text { Sum } \\
\text { Squares }\end{array}$ & Df & Mean Square & & Sig. \\
\hline Regression & 10.059 & 1 & 10.059 & .042 & $.838^{\mathrm{a}}$ \\
\hline Residual & 12421.,367 & 52 & 238.872 & & \\
\hline Total & 12431.426 & 53 & & & \\
\hline
\end{tabular}

a. Predictors: (Constant), gadget

b. Dependent Variable: interaksi

Coefficients $^{\mathrm{a}}$

\begin{tabular}{|c|c|c|c|c|c|}
\hline \multirow[b]{2}{*}{ Model } & \multicolumn{2}{|c|}{$\begin{array}{l}\text { Unstandardized } \\
\text { Coefficients }\end{array}$} & \multirow{2}{*}{\begin{tabular}{|l}
$\begin{array}{l}\text { Standardized } \\
\text { Coefficients }\end{array}$ \\
Beta \\
\end{tabular}} & \multirow[b]{2}{*}{$\mathrm{T}$} & \multirow[b]{2}{*}{ Sig. } \\
\hline & B & Std. Error & & & \\
\hline (Constant) & 62.221 & 11.479 & & 5.420 & .000 \\
\hline Gadget & .079 & .386 & .028 & .205 & .838 \\
\hline
\end{tabular}

a. Dependent Variable: interaksi

Berdasarkan model summary diketahui bahwa nilai dari $\mathrm{R}$ Squaer adalah 0,01 yang berarti $0,1 \%$. Jadi dapat disimpulkan bahwa variabel penggunaan gadget berpengaruh terhadap interasi sosial sebesar $0,1 \%$. Berdasarkan data anova yang merupakan hasil uji $\mathrm{f}$ diketahui hasil $\mathrm{f}$ hitung $=0,042$ dan nilai signifikansi sebesar 0,838. Ketentuan pengambilan sebuah hipotesis diterima atau ditolaknya didasarkan pada besarnya nilai signifikansi. Jika sinifikansi lebih kecil atau sama dengan 0,05 maka hipotesis diterima. Dalam penelitian ini diperoleh hasil nilai signifikansi sebesar $0,838>0,05$. Berdasarkan data koefficiens yaitu data hasil uji $\mathrm{t}$ diketahui bahwa $\mathrm{t}$ hitung penggunaan gadget $=0,205$ dengan nilai signifikansi 0,838 . Penelitian ini diperoleh nilai signifikansi $0,838>0,05$.Sehingga hipotesis yang di ajukan oleh peneliti yaitu ditolak.

Menurut Kulsum \& Jauhar (2014 ) Interaksi sosial merupakan hubungan hubungan sosial yang dinamis, yang menyangkut hubungan antara perorangan seperti hubungan ibu dan anak, antara kelompok-kelompok seperti anggota kelas yang satu dengan kelas yang lain, maupun antara orang perorangan dengan kelompok seperti guru dan muridnya. Apabila dua orang bertemu,interaksi sosial dimulai pada saat itu. Mereka saling menegur, berjabat tangan, saling berbicara atau bahkan berkelahi. Secara istilah gadget berasal dari bahasa Inggris yang artinya perangkat elektronik kecil yang memiliki fungsi khusus. Dalam bahasa Indonesia, gadget disebut “acang”. Manumpil, dkk (2015).

Hasil penelitian diketahui bahwa variabel penggunaan gadget siswa kelas 
$X$ IPS SMA Kristen Satya Wacana Salatiga tahun ajaran 2018/2019 yang berjumlah 54 siswa diperoleh hasil sebesar 44\% dengan jumlah 24 siswa berada pada kategori sedang. Sebesar 39 $\%$ dengan jumlah 21 siswa berada pada kategori tinggi. Sebesar $6 \%$ dengan jumlah 3 siswa berada pada kategori rendah, dan sebesar $11 \%$ dengan jumlah 6 siswa berada pada kategori sangat tinggi. Pada variabel interaksi sosial dapat diketahui bahwa aspek interaksi sosial siswa kelas X IPS SMA Kristen Satya Wacana Salatiga tahun ajaran 2018/2019 yang berjumlah 54 siswa diperoleh hasil sebesar 19\% dengan jumlah 10 siswa berada pada kategori tinggi. Sebesar $11 \%$ dengan jumlah 6 siswa berada pada kategori sangat tinggi. Sebesar 59\% dengan jumlah 32 siswa berada pada kategori rendah, dan sebesar $11 \%$ dengan jumlah 6 siswa berada pada kategori sangat rendah.

Hasil uji hipotesis menunjukan bahwa tidak ada pengaruh yang signifikan antara penggunaan gadget dan interaksi sosial siswa kelas X IPS SMA Kristen Satya Wacana Salatiga dengan memperoleh nilai $\mathrm{f}$ hitung $=0,042$ dengan nilai signifikansi sebesar $0,838>0,05$. Ini membuktikan bahwa tidak terdapat pengaruh secara signifikan antara penggunaan gadget terhadap interaksi sosial. Berdasarkan model summary diketahui bahwa nilai dari $\mathrm{R}$ Squaer adalah 0,01 yang berarti $0,1 \%$. Jadi dapat disimpulkan bahwa variabel penggunaan gadget berpengaruh terhadap interasi sosial sebesar $0,1 \%$. Bahwa dapat berpengaruh dengan faktor - faktor lain.

Hasil penelitian menyatakan bahwa tidak ada pengaruh yang signifikan penggunaan gadget terhadap interaksi sosial siswa. Dari penelitian ini menunjukan bahwa interaksi sosial siswa tidak hanya tergantung pada faktor penggunaan gadget saja melainkan dipengaruhi juga oleh faktor-faktor lainnya. Antara lain faktor imitasi, faktor sugesti, faktor identifikasi, faktor simpati, Gerungan (2004).

Siswa yang memiliki simpati pada orang lain dapat dikatakan bahwa siswa tersebut tertarik terhadap orang lain, atas dasar perasaan atau emosi. Disamping kecenderungan merasa tertarik terhadap orang lain, baik untuk berinteraksi ataupun untuk hal lainya sehingga perasaan tersebut dapat berupa penerimaan terhadap orang lain ataupun penolakan terhadap orang lain. Hal itu juga sependapat dengan Gerungan (2004) Simpati ialah perasaan tertarik terhadap orang lain, atas dasar perasaan atau emosi. Disamping kecenderungan merasa tertarik terhadap orang lain, individu juga 
mempunyai kecenderungan untuk menolak orang lain, yang sering disebut antipati. Jadi faktor simpati tersebut bersifat positif, sedangkan antipati bersifat negatif. Terjadinya sebuah interaksi haruslah mengandung beberapa aspek-aspek interaksi sosial, sebagaimana yang sudah di jelaskan oleh Pasrtowisastro, (2010) bahwa aspek interaksi sosial harus mencakup sebagai berikut: kontak sosial yaitu menjalin hubungan akrab, memperoleh penerimaan dari teman dan dukungan dari teman serta keterbukaan dalam kelompok, individu akan menunjukkan sifat keterbukaan terhadap kelompoknya. Aktifitas bersama, individu bekerja sama dalam kelompok. Individu akan terlibatan dalam kegiatan kelompoknya dan mau menyumbangkan ide bagi kemajuan kelompoknya. Frekuesi hubungan dalam kelompoknya. Individu lebih banyak menngunakan waktunya untuk bertemu dengan anggota kelompoknya dan senang berbicara dalam hubungan yang dekat serta seringnya individu mengunjungi teman.

Di lingkungan sekolah SMA Kristen Satya Wacana Salatiga sudah menunjukkan bagaimana sekolah mengusahakan agar siswa-siswanya lebih senang dalam berinteraksi dengan temannya ketimbang hanya memainkan gadget, hal itu dibuktikan dari hasil penelitian yang menunjukkan bahwa para siswa memiliki interaksi sosial yang tinggi dan penggunaan gadget yang tergolong sedang. Sehingga hal ini tidak lepas dari perhatian sekolah kepada siswa yang membatasi penggunaan gadget di lingkungan sekolah dengan tujuan agar siswa menjalin interaksi sosial dengan temanya menjadi lebih baik. Hasil penelitian ini sejalan dengan penelitian Agus (2014) dengan judul "pengaruh penggunaan smartphone terhadap interaksi sosial siswa di SMK Kristen BM Salatiga".

Hasil analisis menunjukkan bahwa tidak ada pengaruh yang signifikan antara penggunaan smartphone terhadap interaksi sosial siswa kelas X SMK Kristen BM Salatiga tahun ajaran 2017/2018. Hasil penelitian ini sejalan dengan Chusna(2017) dengan judul tentang "Pengaruh Penggunaan Gadget Dan Lingkungan Belajar Terhadap interaksi sosial Siswa Kelas XI Kompetensi Keahlian Administrasi Perkantoran SMK Muhammadiyah 2 Yogyakarta". Hasil analisis menunjukkan bahwa adanya pengaruh yang signifikan antara penggunaan gadget terhadap interaksi sosial siswa kelas XI Kompetensi Keahlian Administrasi 
Perkantoran SMK Muhammadiyah 2 Yogyakarta.

\section{PENUTUP}

Berdasarkan penelitian yang telah dilakukan terhadap siswa kelas X IPS SMA Kristen Satya Wacana Salatiga, maka dapat diambil simpulan bahwa tidak terdapat pengaruh yang signifikan antara penggunaan gadget terhadap interaksi sosial siswa kelas X IPS SMA Kristen Satya Wacana Salatiga Tahun Ajaran 2018/2019. Berdasarkan simpulan di atas, maka peneliti mengajukan beberapa saran sebagai tindak lanjut dari penelitian ini sebagai berikut:

Berdasarkan hasil temuan dalam penelitian ini, penulis menyarankan agar siswa dapat menggunakan gadget secara cerdas dan lebih bijak lagi dalam menggunakan gadget guna untuk mempermudah berinteraksi dengan lingkungan sosial disekitarnya dari pada lebih memilih memainkan gadget untuk hal-hal yang tidak bermanfaat. Berdasarkan hasil penelitian yang menunjukkan siswa kelas X IPS SMA Kristen Satya Wacana Salatiga memiliki siswa yang lebih suka berinteraksi secara face to face atau langsung kategori tinggi dan penggunaan gadget yang tergolong sedang, maka hendaknya Guru BK dapat memberikan layanan bimbingan dan konseling yang dapat meningkatkan interaksi sosial dengan cara mengikuti kegiatan - kegiatan yang ada di sekolah.

\section{DAFTAR PUSTAKA}

Ameliola, Nugraha. 2013. Perkembangan Media Informasi dan Teknologi Terhadap Anak dalam Era Globalisasi. [Internet] Diakses dari

http://icssis.files.wordpress.com/2 013/09/2 013-0229 pada tanggal 26 Desember 2018

Agung, Prasetio. 2017. Pengaruh Penggunaan Smart Phone Terhadap Interaksi Sosial Siswa $\begin{array}{llll}\text { Kelas } & X & S M K & B M\end{array}$ Salatiga.(Skripsi) Institutional Repositori | Satya Wacana Christian Universiti,Salatiga.

Agung, Prabowo. 2016. Pengaruh Gadget Terhadap Anak Dalam Interaksi Keluarga Muslim Perumahan Wingong Kota Gede.(Skripsi) Universitas Islam Sunan Kalijaga Yogyakarta.

Azwar, Saifuddin. 2012. Penyusunan Skala Psikologi. Jakarta. Yogyakarta : Pustaka Pelajar.

Christiany, Juditha. 2011. Hubungan Penggunaan Situs Jejaring Sosial Facebook Terhadap Perilaku Remaja di Kota Makasar. Jurnal Penelitian IPTEK-KOM. Nomor 1, Volume 13(1-23).

Gerungan. 2004. Psikologi Sosial. Bandung: PT Reflika Aditama

Osa, Kurniawan Ilham. (2011).(artikel) Gadget, makanan apa itu?.Diakses dari m.kompasiana.com/osakurniawan ilham/gadget-makanan-apa-itu pada tanggal 23 Agustus 2018 pukul 15.22 WIB 
Partowisastro, H. Koestoer. 2007. Dinamika Psikologi Sosial. Jakarta:Erlangga.

Sugiyono. 2012. Metode Penelitian Kuantitatif, Kualitatif dan $R \& D$. Bandung: Alfabeta.

Siyomukti, N. 2016. Pengantar Sosiologi - Dasar Analisis, Teori, \& Pendekatan Menuju Analisis Masalah-Masalah Sosial Dan Kajian Strategi. Ar-Ruzz Media.

Widiawati \& Sugiman. 2014. Pengaruh Penggunaan Gadget Terhadap Daya Kembang Anak.[Online]Diaksesdarilamanht tp://stmikglobal.ac.id/wpcontent/u ploads/2014/05/artikeLIIS.

Diakses pada tanggal 26 Desember 2018

Widiawati\&Sugiman. 2014. Gadget. Google Book.(internet) Hasil Survey Kebiasaan Pengguna Smartphone diIndonesia. Viva News (31 Juli).

Yudit Ismanto. 2015. Hubungan penggunaan gadget dengan tingkat prestasi siswa di SMA Negeri 9 Manado. Jurnal keperawata Manado. FK UNSRUT Manado. Vol.3(2).

Yordi Anugrah Pertama. 2015. Dampak Positif dan Negatif dalam Menggunakan Gadget. Diakses dari (internet) www.jendelaberita.com/2015/dam pak-positif-dan-negatif-dalammenggunakan-gadget/pada tanggal 9 September 2018 pukul 09.30 WIB 